\title{
PENGARUH KINERJA KEUANGAN DAERAH TERHADAP ALOKASI BELANJA MODAL DI PROVINSI BALI
}

\author{
Ni Made Deni Indiyanti ${ }^{1}$ \\ Henny Rahyuda ${ }^{2}$ \\ ${ }^{1,2}$ Fakultas Ekonomi Dan Bisnis Universitas Udayana, Bali, Indonesia \\ Email: deniindiyanti@gmail.com
}

\begin{abstract}
ABSTRAK
Pengelolaan keuanga daerah yang baik harus didukung dengan kemampuan keuangan daerah yang memadai sehingga dapat menyebabkan pada peningkatan pelayanan dan kesejahteraan masyarakat. Pemerintah dapat mewujudkan hal tersebut, jika pengeluaran yang dilakukan pemerintah untuk pelayanan dan kesejahteraan masyarakat, berupa belanja modal harus mendapat porsi relatif besar. Tujuan dari penelitian ini adalah untuk mengetahui pengaruh kinerja keuangan daerah terhadap alokasi belanja modal. Penelitian ini dilakukan di seluruh kabupaten/kota di Provinsi Bali periode tahun 2012-2016. Hasil penelitian ini menunjukkan bahwa kinerja keuangan daerah yang diukur dengan rasio derajat desentralisasi fiskal, kemandirian keuangan daerah, tingkat pembiayaan SiLPA, dan derajat kontribusi BUMD berpengaruh positif signifikan terhadap alokasi belanja modal. Sementara itu, kinerja keuangan daerah yang diukur dengan rasio efektivitas pendapatan asli daerah (PAD), dan efisiensi keuangan daerah berpengaruh negatif tidak signifikan terhadap alokasi belanja modal.
\end{abstract}

Kata kunci : pengelolaan keuangan daerah, kinerja keuangan daerah, belanja modal

\begin{abstract}
Regional financial management is better when government supported with capability of adequate regional financial, so it's can impact on improving services and community welfare. The government can do it, if government spending on services and community welfare, in the form of capital expenditure should get a relatively large portion. The purpose of this study is to determine the effect of regional financial performance to the allocation of capital expenditure. This research was conducted in all regency Province of Bali for the period of 2012-2016. The results of this study indicate that local financial performance as measured by the degree of fiscal decentralization ratio, regional financial independence, SiLPA financing rate, and the degree of BUMD contribution have a positive influence significantly to the allocation of capital expenditure. Meanwhile, the regional financial performance as measured by the ratio of the effectiveness of regional revenue, the efficiency of regional finance have a negative influance not significantly to the allocation of capital expenditure.
\end{abstract}

Keywords: regional financial management, regional financial performance, capital expenditure 
Ni Made Deni Indiyanti, Pengaruh Kinerja Keuangan Daerah...

\section{PENDAHULUAN}

Undang-Undang No. 33 tahun 2004 pasal 66 ayat 1 menjelaskan otonomi daerah akan berhasil, jika didukung oleh kinerja pemerintah dalam mengelola keuangan daerahnya dengan tertib, ekonomis, taat pada peraturan perundangundangan, efisien, efektif, transparan, dan bertanggungjawab. Pengelolaan keuangan daerah menggunakan pendekatan kinerja yang berorientasi output, konsep nilai uang (value for money), dan penerapan prinsip tata kelola pemerintahan yang baik. Kinerja pemerintah dinilai melalui anggaran yang dibuatnya, sehingga diharapkan pengeluaran yang dilakukan pemerintah ditunjukan untuk pelayanan kepada masyarakat, berwujud dalam belanja modal, harus mendapatkan porsi yang relatif besar (Halim, 2008: 226).

Doh-Nani and Awunyo-Vitor (2012) menemukan bahwa belanja dan pendapatan suatu negara saling berhubungan. Amuka et al. (2016) menemukan bahwa belanja modal merupakan salah satu komponen belanja pemerintah. Bojanic (2013) mengemukakan belanja modal termasuk investasi dibidang infrastruktur, amortisasi modal utang publik, dan transfer modal untuk pemerintah daerah, perusahaan dikelola negara, dan beberapa lembaga pemerintah yang terdesentralisasi. Nwosu and Okafor (2014) mengemukakan bahwa pemerintah harus mengurangi ukuran pengeluaran berulang yang besar, beralih ke pengeluaran modal dan pengeluaran investasi lainnya untuk mencegah besarnya defisit anggaran. Rinaldi (2012) menemukan bahwa belanja langsung dalam bentuk investasi belanja modal akan berdampak pada apresiasi masyarakat dalam bentuk kepuasan kualitas pelayanan dan meningkatkan sumber pendapatan 
daerah. Egbetude and Fasanya (2014), menemukakan bahwa belanja publik yang lebih banyak dialokasikan pada belanja berulang daripada belanja modal tidak mampu mempengaruhi pertumbuhan ekonomi.

Kayode et al. (2015) menemukan bahwa belanja modal berpengaruh positif terhadap pertumbuhan ekonomi. Venkatarama and Urmi (2017), menunjukkan bahwa beberapa pemerintah mencoba untuk mulai meningkatkan belanja publik dalam rangka mendorong pertumbuhan ekonomi. Abu and Abdullahi (2010) menyatakan pengalokasian terhadap belanja modal sebaiknya dilakukan dengan pertimbangan yang cukup baik sehingga dapat mewujudkan peningkatan terhadap pelayanan publik yang diinginkan. Fasoranti (2012) menyatakan bahwa pemerintah harus mengendalikan pengeluaran untuk pemenuhan infrastruktur dan menjadikan sebagai prioritas utama, agar mendorong peningkatan laju pertumbuhan ekonomi.

Permendagri Nomor 13 tahun 2006 menjelaskan bahwa belanja modal yaitu bagian dari kelompok belanja daerah, berupa pengeluaran dalam rangka pembelian suatu pembangunan aset tetap berwujud dengan nilai manfaat lebih dari dua belas bulan digunakan pada kegiatan pemerintahan. Patricia and Izuchukwun (2013) mengemukakan bahwa pengalokasian belanja daerah yang lebih ditekankan pada belanja modal oleh pemerintah dapat mempercepat pertumbuhan ekonomi dan meningkatkan taraf hidup masyarakat di daerah tersebut. 


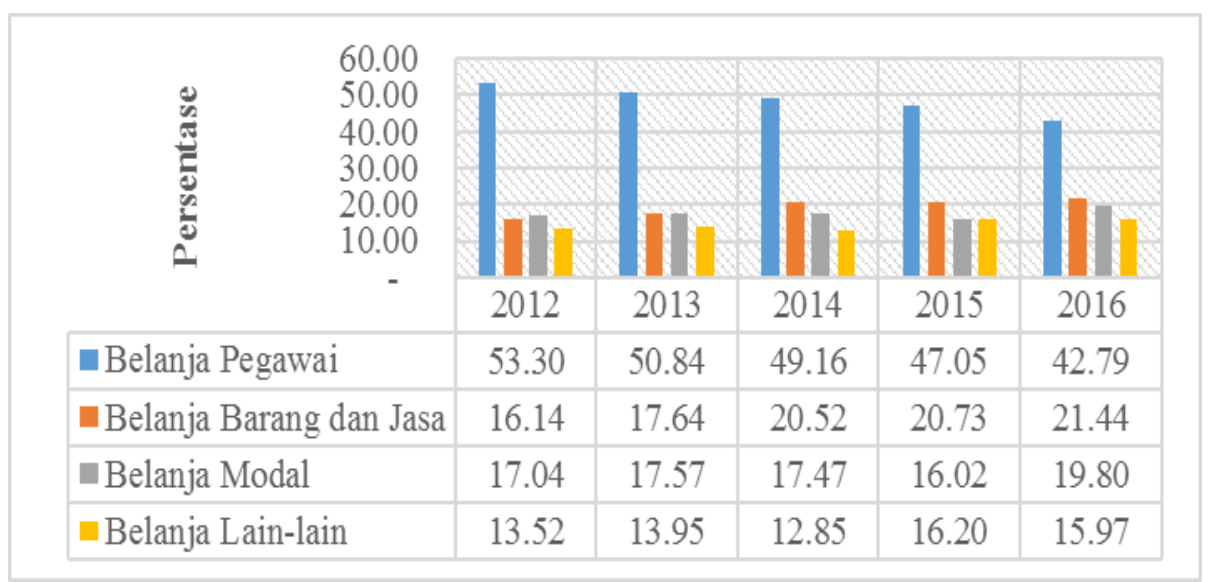

Gambar 1. Trend Belanja Daerah Provinsi Bali Tahun 2012-2016 (persen) Sumber: Data Diolah, 2018

Gambar 1 menunjukkan proporsi tiap jenis belanja daerah dan trend kenaikan atau penurunan setiap tahunnya di Provinsi Bali. Belanja pegawai (langsung dan tidak langsung) masih mendominasi belanja daerah di Provinsi Bali, walaupun pada rentang waktu 2012-2016 belanja pegawai terus mengalami penurunan. Belanja pegawai pada rentang waktu 2012-2013 berada diatas 50 persen, namun pada tahun 2014-2016 berada dibawah 50 persen. Berbeda dengan belanja pegawai, belanja barang dan jasa di Provinsi Bali pada rentang waktu 2012-2016 terus mengalami peningkatan setiap tahunnya. Peningkatan terbesar terjadi pada tahun 2013 ke tahun 2014, yakni sebesar 2, 88 persen. Belanja daerah yang ditunjukkan untuk belanja modal juga menunjukan trend yang berbeda, pada tahun 2013 belanja modal mengalami kenaikan namun sebaliknya pada tahun 2015 belanja modal mengalami penurunana sedangkan pada tahun 2016 belanja modal kembali mengalami kenaikan menjadi 19,80 persen. Belanja lain-lain juga mengalami kenaikan dan penurunan dalam rentang waktu 2012-2016. Pada tahun 2013 belanja lain-lain mengalami kenaikan dari tahun sebelumnya, kemudian 
mengalami penurunan pada tahun 2014 dan kenaikan pada tahun 2015 dan kembali mengalami penurunan pada tahun 2016.

Pemerintah daerah di provinsi Bali lebih besar mengalokasikan belanja daerahnya ke belanja pegawai dibandingkan belanja modal. Alokasi yang ditunjukkan untuk belanja pegawai bahkan mencapai 50 persen, namun alokasi belanja daerah yang ditunjukkan untuk belanja modal tidak mencapa 20 persen. Jika dibandingkan dengan belanja daerah yang dialokasikan terhadap belanja barang dan jasa yang terus mengalami peningkatan, alokasi terhadap belanja modal masih lebih rendah. Rendahnya alokasi terhadap belanja modal dan juga terjadinya penurunan terhadap alokasi belanja modal, menunjukkan kurangnya perhatian pemerintah pada belanja yang bersifat produktif dan dapat digunakan untuk meningkatkan pertumbuhan ekonomi daerah dan kesejahteraan masyarakat di daerah.

Jin and Jianhui (2011), menyatakan bahwa daerah yang masih dalam tahap pembangunan ekonomi, peningkatan pengeluaran produktif dapat merangsang pertumbuhan ekonomi dan berefek lebih baik dari pengeluaran non produktif. Coestzee and Kleynhans (2017) menyatakan bahwa pasokan yang cukup dari infrastruktur sangat penting untuk memastikan peningkatan produktivitas dan pertumbuhan ekonomi. Usman et al. (2011) menyatakan bahwa belanja publik memiliki dampak jangka panjang terhadap pertumbuhan ekonomi. Udoka and Anyingang (2015) menyatakan bahwa belanja modal yang dimiliki dapat berdampak terhadap pertumbuhan dan perkembangan ekonomi. 
Ni Made Deni Indiyanti, Pengaruh Kinerja Keuangan Daerah...

Upaya pemerintah daerah untuk meningkatan kemampuan keuangan daerah tercermin dari kinerja keuangan daerah (Arsa dan Setiawina, 2015). Mahsun dkk. (2007:157) menyatakan kinerja keuangan daerah merupakan suatu bentuk hasil pencapaian yang dimiliki oleh pemerintah daerah berdasarkan hasil perbandingan realisasi pendapatan ataupun belanja yang diterima dan dikeluarkan oleh pemerintah daerah dengan jumlah pendapatan dan belanja yang telah dianggarkan oleh pemerintah sebelumnya dalam APBD. Puspaningsih dan Aryani (2016), mengemukakan bahwa kinerja keuangan dilakukan untuk mengukur tingkat pertanggungjawaban (accountability) pemerintah daerah dan tingkat kemandirian keuangan pemerintah daerah dalam menjalankan prinsip otonomi daerah.

Pemerintah daerah menggunakan sumber pendapatannya lebih besar untuk belanja modal, namun prakteknya pemerintah kesulitan untuk meningkatkan belanja modal daerahnya karena adanya moral hazard. Riswan dan Affandi (2014) mengemukakan bahwa kinerja keuangan yang baik berpengaruh positif pada belanja modal untuk pelayanan publik. Perubahan kinerja keuangan daerah berdampak pada perubahan alokasi belanja modal daerah tersebut (Prihastuti dkk., 2015). Baik tidaknya kinerja keuangan daerah dapat dilihat dengan melakukan analisis rasio keuangan. Indikator kinerja keuangan daerah yang digunakan dalam penelitian ini yakni, rasio derajat desentralisasi fiskal, rasio kemandirian keuangan, rasio efektivitas $\mathrm{PAD}$, rasio efisiensi keuangan daerah, rasio tingkat pembiayaan Sisa Lebih Perhitungan Anggaran, dan kontribusi BUMD.

Rasio Derajat desentralisasi menunjukkan derajat kontribusi Pendapatan Asli Daerah (PAD) pada total pendapatan daerah (Halim dan Damayanti 
(2007:262). Praza (2016), dan Arsa dan Setiawina (2015) menemukan derajat desentralisasi fiskal berpengaruh positif signifikan terhadap alokasi belanja modal. Suwandi dan Tahar (2015) menemukan pengaruh negatif signifikan rasio derajat desentralisasi fiskal pada alokasi belanja modal. Rasio densentralisasi fiskal ditemukan tidak berpengaruh pada alokasi belanja modal oleh Badrudin (2011), Sularso dan Restianto (2011) dan Tamawiwy dkk. (2016).

Rasio kemandirian keuangan daerah mencerminkan keadaan otonomi suatu daerah diukur dengan membandingkan pendapatan asli daerah dan jumlah total pendapatan daerah yang bersumber dari bantuan pemerintah pusat, provinsi, dan pinjaman (Halim, 2008: 232). Rasio kemandirian keuangan daerah ditemukan berpengaruh positif signifikan terhadap alokasi belanja modal oleh Jatitmas (2015), bertentangan dengan penelitian Gerungan dkk. (2015) menemukan rasio kemandirian keuangan daerah berpengaruh negatif signifikan terhadap alokasi belanja modal . Arsa dan Setiawina (2015) menyatakan tidak ada pengaruh rasio kemandirian keuangan daerah terhadap alokasi belanja modal.

Rasio Efektivitas Pendapatan Asli Daerah (PAD), menggambarkan kemampuan pemerintah daerah dalam merealisasikan pendapatan asli daerah (PAD) direncanakan dibandingkan dengan target yang ditetapkan berdasarkan potensi riil suatu daerah (Halim, 2008: 234). Hidayat (2013), Suwandi dan Tahar (2015), Arsa dan Setiawina (2015), Sularso dan Restianto (2011), Jatitmas (2015), dan Gerungan dkk. (2015) menemukan rasio efektivitas berpengaruh positif signifikan pada alokasi belanja modal. Praza (2016) menemukan rasio efektivitas PAD tidak berpengaruh terhadap alokasi belanja modal. Martini dan 
Ni Made Deni Indiyanti, Pengaruh Kinerja Keuangan Daerah...

Dwirandra (2015) dan Tamawiwy dkk. (2016) menemukan pengaruh positif tidak signifikan rasio efektivitas PAD pada alokasi belanja modal.

Rasio efisiensi keuangan daerah merupakan perbandingan besarnya pengeluaran untuk memperoleh pendapatan dengan realisasi pendapatan yang diterima (Halim, 2008: 234). Ardhini dan Handayani (2011) dan Martini dan Dwirandra (2015) menemukan pengaruh negatif signifikan rasio efisiensi keuangan daerah pada aloaksi belanja modal bertentangan dengan Hafidh (2013), Jatitmas (2015), dan Gerungan dkk. (2015) menemukan rasio efisiensi keuangan daerah berpengaruh positif signifikan pada alokasi belanja modal. Tamwiwy dkk. (2016) menyatakan efisiensi keuangan daerah berpengaruh positif tidak signifikan pada aloaksi belanja modal.

Rasio tingkat pembiayaan SiLPA diukur dengan membandingkan SiLPA dan total belanja daerah (Hidayat, 2013). Hidayat (2013) menemukan pengaruh positif signifikan rasio tingkat pembiayaan SiLPA pada alokasi belanja modal. Martini dan Dwirandra (2015) menemukan rasio tingkat pembiayaan SiLPA berpengaruh negatif signifikan pada alokasi belanja daerah.

Rasio Derajat kontribusi BUMD bermanfaat untuk mengetahui tingkat kontribusi perusahaan daerah dalam mendukung pendapatan daerah. Sularso dan Restianto (2011) menemukan bahwa rasio derajat kontribusi BUMD berpengaruh signifikan terhadap alokasi belanja modal. Bertentangan dengan Martini dan Dwirandra (2015) yang menemukan rasio derajat kontribusi BUMD berpengaruh positif tidak signifikan pada alokasi belanja modal. Praza (2016) menyatakan derajat kontribusi BUMD berpengaruh negatif signifikan terhadap alokasi belanja 
modal. Suwandi dan Tahar (2015) dan Arsa dan Setiawina (2015) menyatakan rasio derajat kontribusi BUMD tidak berpengaruh terhadap alokasi belanja modal. Berdasarkan uraian latar belakang masalah sebelumnya, maka dapat dirumuskan pokok permasalahan sebagai berikut: 1) Apakah rasio derajat desentralisasi fiskal berpengaruh signifikan terhadap alokasi belanja modal? 2) Apakah rasio kemandirian keuangan daerah berpengaruh signifikan terhadap alokasi belanja modal? 3) Apakah rasio efektifitas PAD berpengaruh signifikan terhadap alokasi belanja modal? 4) Apakah rasio efesiensi keuangan daerah berpengaruh signifikan terhadap alokasi belanja modal? 5) Apakah rasio tingkat pembiayaan SiLPA berpengaruh signifikan terhadap alokasi belanja modal? 6) Apakah rasio derajat kontribusi BUMD berpengaruh signifikan terhadap alokasi belanja modal?

Tujuan dari penelitian yaitu 1) Untuk mengetahui signifikansi pengaruh rasio derajat desentralisasi fiskal terhadap alokasi belanja modal, 2) Untuk mengetahui signifikansi pengaruh rasio kemandirian keuangan terhadap alokasi belanja modal, 3) Untuk mengetahui signifikansi pengaruh rasio efektivitas PAD terhadap alokasi belanja modal, 4) Untuk mengetahui signifikansi pengaruh rasio efisiensi keuangan daerah terhadap alokasi belanja modal, 5) Untuk mengetahui signifikansi pengaruh rasio tingkat pembiayaan SiLPA terhadap alokasi belanja modal, 6) Untuk mengetahui signifikansi pengaruh rasio derajat kontribusi BUMD terhadap alokasi belanja modal. Manfaat teoritis dari penelitian ini yakni, diharapkan dapat memberikan bukti empiris pengaruh kinerja keuangan daerah pada pengaloaksian belanja modal dan memberikan pemahaman yang lebih baik 
Ni Made Deni Indiyanti, Pengaruh Kinerja Keuangan Daerah...

mengenai pengaruh kinerja keuangan daerah pada pengalokasian belanja modal. Manfaat praktis dari penelitian ini yakni, diharapkan bermanfaat bagi pemerintah daerah sebagai bahan informasi, acuan, dan juga sebagai masukan dalam peningkatan pengelolaan keuangan daerahnya.

Desentralisasi membuat pemerintah daerah lebih kompeten dalam pengelolaan urusanya sendiri (Rosemary et al. 2016). Bastian (2001:261) menyatakan, secara umum perubahan kewenangan pembelanjaan maupun penerimaan anggaran, merupakan akibat pelaksanaan desentralisasi fiskal, dapat mempengaruhi kemampuan pemerintah pusat melakukan kebijakan ekonomi makro melalui anggaran negara. Pemerintah mempunyai wewenang lebih luas untuk mengelola keuangan daerahnya dengan adanya desentralisasi fiskal, sehingga alokasi belanja modal untuk pemenuhan kebutuhan masyarakat, dapat ditingkatkan (Huda, 2015). Semakin tinggi rasio derajat desentralisasi fiskal suatu daerah, maka kemampuan daerah tersebut untuk mengalokasikan belanja daerahnya ke belanja modal akan lebih tinggi. Hasil penelitian yang menemukan bahwa derajat desentralisasi fiskal berpengaruh positif signifikan terhadap alokasi belanja daerah ditemukan juga oleh Arsa dan Setiawina (2015), Praza (2016), dan Huda (2015).

$\mathrm{H}_{1}$ : Rasio derajat desentralisasi fiskal berpengaruh positif signifikan terhadap alokasi belanja modal.

Mahmudi (2010: 26) menyatakan bahwa rasio kemandirian keuangan daerah mennjelaskan tentang ketergantungan daerah terhadap sumber dana eksternal. Rasio kemandirian yang tinggi keuangan daerah maka, semakin rendah ketergantungan daerah pada bantuan pihak luar. Rasio kemandirian keuangan 
daerah juga, menggambarkan tingginya partisispasi masyarakat dalam membayar pajak dan retribusi daerah yang merupakan komponen utama PAD (Halim, 2008: 233). Saruc and Sagbas (2008) berpendapat bahwa efek transfer terhadap upaya pajak pemerintah daerah dapat diamati melalui tingkat pengeluaran pemerintah daerah. Partisipasi masyarakat yang semakin tinggi dalam membayar pajak dan retribusi seharusnya diimbangi penyediaan infrastruktur atau aset tetap oleh pemerintah daerah untuk meningkatkan kesejahteraan masyarakatnya diwujudkan dengan pengalokasian belanja modal. Hasil penelitian yang menyatakan rasio kemandirian keuangan daerah berpengaruh positif signifikan terhadap alokasi belanja modal ditemukan juga oleh Sularso dan Restianto (2011) dan Jatitmas (2015).

$\mathrm{H}_{2}$ : Rasio kemandirian keuangan daerah berpengaruh positif signifikan terhadap aloaksi belanja modal

Semakin tinggi rasio efektivitas suatu daerah maka semakin baik kinerja dari daerah tersebut (Halim, 2008: 234). Nugroho dan Rohman (2012) menemukan bahwa peningkatan pendapatan asli daerah (PAD) diharapkan dapat meningkatkan investasi belanja modal pemerintah daerah sehingga kualitas pelayanan publik semakin baik. Hal tersebut menjelaskan semakin tinggi rasio efektivitas PAD suatu daerah maka alokasi belanja daerah akan meningkat. Beberapa hasil penelitian yang juga menemukan hubungan positif efektivitas PAD terhadap alokasi belanja modal suatu daerah yaitu Hidayat (2013), Arsa dan Setiawian (2015) dan Jatitmas (2015). Berdasarkan kajian teori dan empiris tersebut maka dapat dirumuskan hipotesis sebagai berikut: 
Ni Made Deni Indiyanti, Pengaruh Kinerja Keuangan Daerah...

$\mathrm{H}_{3}$ : Rasio efektivitas pendapatan asli daerah (PAD) berpengaruh positif signifikan terhadap alokasi belanja modal.

Semakin kecil rasio ini, maka kinerja pemerintah daerah dapat dikatakan baik, begitu pula sebaliknya (Halim, 2008: 234). Kinerja yang baik akan mengakibatkan peningkatan terhadap belanja modal daerah tersebut. Rasio efisiensi yang tinggi menunjukkan penggunaan keuangan daerah tidak efisien, karena lebih besarnya jumlah realisasi pengeluaran daripada pendapatan yang diterima, sehingga terjadi pemborosan belanja tapi tidak dialokasikan secara tepat untuk belanja modal (Ardhini dan Handayani 2011). Terdapat persamaan hasil penelitian Ardhini dan Handayani (2011) dan Martini dan Dwirandra (2015) yang menemukan rasio efisiensi keuangan daerah berpengaruh negatif signifikan terhadap belanja modal. Berdasarkan kajian teori dan empiris tersebut maka dapat dirumuskan hipotesis sebagai berikut:

$\mathrm{H}_{4}$ : Rasio efisiensi keuangan daerah berpengaruh negatif signifikan terhadap alokasi belanja modal.

Sisa Lebih Perhitungan Anggaran Tahun Anggaran Sebelumnya (SiLPA) diindikasikan menjadi salah satu sumber pendanaan belanja modal untuk pelayanan publik. SiLPA tahun lalu yang besar pada struktur penerimaan pendapatan menjadi pertimbangan pemerintah daerah untuk meningkatkan pengalokasian belanja modal. Hal tersebut berarti kenaikan tingkat pembiayaan SiLPA tahun lalu maka, alokasi belanja modal tahun berikutnya juga meningkat. Ardhini dan Handayani (2011) dan Hidayat (2013) menemukan bahwa rasio tingkat pemabiayaan SiLPA berpengaruh positif signifikan terhadap alokasi 
belanja modal. Berdasarkan kajian teori dan empiris tersebut maka dapat dirumuskan hipotesis sebagai berikut:

$\mathrm{H}_{5}$ : Rasio tingkat pembiayaan SiLPA berpengaruh positif signifikan terhadap alokasi belanja modal.

Tingkat kontribusi perusahaan daerah/BUMD dalam mendukung pendapatan daerah diguanak derajat kontribusi BUMD. Semakin tinggi rasio ini berdampak pada naiknya pendapatan daerah (Sularso dan Restianto, 2011). Derajat kontribusi yang tinggi menunjukkan kemampuan keuangan daerah menjadi lebih tinggi sehingga memungkinkan pengalokasian yang lebih besar terhadap belanja modal. Sejalan dengan penelitian yang dilakukan oleh Sularso dan Restianto (2011) menunjukkan bahwa derajat kontribusi BUMD mempunyai pengaruh positif signifikan terhadap alokasi belanja modal. Berdasarkan kajian teori dan empiris tersebut maka dapat dirumuskan hipotesis sebagai berikut:

$\mathrm{H}_{6}$ : Rasio derajat kontribusi BUMD berpengaruh positif signifikan terhadap alokasi belanja modal.

\section{METODE PENELITIAN}

Penelitian ini menggunakan pendekatan kuantitatif yang berbentuk asosiatif. Penelitian ini dilakukan di seluruh kabupaten/kota di provinsi Bali periode 2012-2016. Variabel terikat yang digunakan dalam penelitian ini yaitu alokasi belanja modal (Y). Variabel bebas dalam penelitian ini yaitu kinerja keuangan daerah diukur dengan rasio derajat desentralisasi fiskal (X1), rasio kemandirian keuangan daerah (X2), rasio efektivitas pendapatan asli daerah (PAD) (X3), rasio efisiensi keuangan daerah (X4), rasio tingkat pembiayaan SiLPA (X5), dan rasio derajat kontribusi BUMD (X6). 
Ni Made Deni Indiyanti, Pengaruh Kinerja Keuangan Daerah...

Alokasi belanja modal merupakan anggaran untuk memperoleh aset tetap dan aset lainnya, memiliki masa manfaat duabelas bulan. Alokasi belanja modal dapat dihitung dengan formulasi sebagai berikut:

Alokasi Belanja $=\frac{\text { Jumlah Belanja Modal }}{\text { Total Belanja Drah }} \times 100 \%$

Rasio derajat desentralisasi fiskal merupakan perbandingan antara Pendapatan Asli Daerah (PAD) PAD tahun lalu (t-1) dengan total pendapatan daerah PAD tahun lalu (t-1) pada periode 2012-2016. Rasio derajat desentraslisasi fiskal dapat dihitung dengan formulasi sebagai berikut:

Rasio Derajat Desentralisasi $=\frac{\text { PendapatanAsli Daerah }}{\text { Total Pendapatan Derah }} \times 100 \%$

Rasio kemandirian keuangan daerah dalam penelitian ini merupakan perbandingan Pendapatan Asli Daerah (PAD) PAD tahun lalu (t-1) dengan transfer pusat, provinsi, dan pinjaman PAD tahun lalu (t-1) pada periode 20122016. Rasio kemandirian keuangan daerah dihitung dengan formulasi sebagai berikut:

Rasio Kemandirian $=\frac{\text { PendapatanAsli Daerah }}{\text { Traffer Pusart Provinsi Pingaman }} \times 100 \%$

Rasio efektivitas PAD diukur dengan membandingkan realisasi penerimaan PAD tahun lalu ( $\mathrm{t}-1)$ dengan target penerimaan PAD yang ditetapkan PAD tahun lalu (t-1) pada periode 2012-2016. Rasio efektivitas PAD dihitung dengan formulasi sebagai berikut:

Rasio Efektivitas $=\frac{\text { Realirasi Penerimaan PAD }}{\text { Target Penerimaan PAD yang Dittaphan }} \times 100 \%$

Rasio efisiensi keuangan daerah diukur dengan membandingkan pengeluaran untuk memperoleh pendapatan periode tahun lalu (t-1) dengan 
realisasi penerimaan pendapatan periode tahun lalu (t-1) pada periode 2012-2016. Rasio efisiensi keuangan daerah dihitung dengan formulasi sebagai berikut:

Rasio Efektivitas $=\frac{\text { Total Realizasi Belanja Dasrah }}{\text { Total Realíasi Penerimaan Pendapatan }} \times 100 \%$

Tingkat pembiayaan SiLPA diukur dengan membandingkan SiLPA pada dua tahun sebelumnya ( $\mathrm{t}-2)$ dibandingkan dengan total belanja tahun lalu ( $\mathrm{t}-1)$ pada periode 2012-2016. Rasio ini dihitung dengan formulasi sebagai berikut:

Tingkat Pembiayaan SiLPA $=\frac{\text { SiLPA }}{\text { Total Belanja }} \times 100 \%$

Rasio derajat kontribusi BUMD diukur dengan membandingkan penerimaan bagian laba BUMD tahun lalu (t-1) dibandingkan dengan penerimaan PAD tahun lalu (t-1), periode tahun 2012-2016. Rasio ini dihitung dengan formulasi sebagai berikut:

$\begin{aligned} & \text { Rasio Derajat Kontribusi } \\ & \text { BUMD }\end{aligned}=\frac{\text { Penerimaan Bagian Laba BUMD }}{\text { Penerimaan PAD }} \times 100 \%$

Jenis data yang digunakan dalam penelitian ini yaitu data kuantitatif dan data kualitatif. Data sekunder pada penelitian ini adalah laporan statistik keuangan pemerintah kabupaten dan kota di provinsi Bali, tahun 2010-2014, tahun 20112015, dan tahun 2012-2016 diperoleh dari Badan Pusat Statistika (BPS) Provinsi Bali yang juga dapat diakses melalui situs www.bali.bps.go.id. Populasi dan sampel pada penelitian ini adalah seuruh kabuapaten/kota yang ada di provinsi Bali terdiri dari delapan kabupaten dan satu pemerintahan kota periode tahun 2012-2016. Metode penentuan sampel yang digunakan dalam penelitian ini adalah teknik sampling jenuh. Metode pengumpulan data yang pada penelitian ini yaitu metode observasi non partisipan. Teknik analisis data yang digunakan pada 
penelitian ini yaitu analisis regresi linear berganda dengan bantuan program SPSS versi 23. Model regresi linear berganda yang dimaksud dirumuskan sebagai berikut (Utama, 2014:77):

$$
\mathrm{Y}=\alpha+\beta 1 X 1+\beta 2 X 2+\beta 3 X 3+\beta 4 X 4+\beta 5 X 5+\beta 6 X 6 \varepsilon i
$$

Keterangan :

$\mathrm{Y}=$ Alokasi Belanja Modal

$\mathrm{X}_{1} \quad=$ Rasio Derajat Desentralisasi Fiskal

$\mathrm{X}_{2} \quad=$ Rasio Kemandirian Keuangan Daerah

$\mathrm{X}_{3}=$ Rasio Efektivitas PAD

$\mathrm{X}_{4} \quad=$ Rasio Efisiensi Keuangan Daerah

$\mathrm{X}_{5} \quad=$ Rasio Tingkat Pembiayaan SiLPA

$\mathrm{X}_{6}=$ Rasio Derajat Kontribusi BUMD

$\alpha \quad=$ Konstanta

$\beta_{1}=\beta_{2}=\beta_{3}=\beta_{4}=\beta_{5}=\beta_{6}=$ Koefisien regresi masing-masing $\mathrm{Xi}$

si $=$ Variabel Pengganggu

\section{HASIL DAN PEMBAHASAN}

Tabel 1.

Hasil Analisis Statistik Deskriptif

\begin{tabular}{lrrrrr}
\hline & N & $\begin{array}{c}\text { Mini- } \\
\text { mum }\end{array}$ & Maximum & Mean & $\begin{array}{c}\text { Std. } \\
\text { Deviation }\end{array}$ \\
\hline Rasio Derajat Desentralisasi Fiskal & 45 & 4.23 & 80.36 & 24.2033 & 21.28426 \\
Rasio Kemandirian Keuangan Daerah & 45 & 4.41 & 409.11 & 60.0324 & 105.34708 \\
Rasio Efektivitas PAD & 45 & 91.00 & 236.28 & 130.8713 & 21.54338 \\
Rasio Efisiensi Keuangan Daerah & 45 & .09 & 108.36 & 95.0444 & 15.02209 \\
Rasio Tingkat Pembiayaan SiLPA & 45 & 3.62 & 32.64 & 12.5593 & 7.20125 \\
Rasio Derajat Kontribusi BUMD & 45 & 1.65 & 12.75 & 5.3893 & 2.84784 \\
Alokasi Belanja Modal & 45 & 5.57 & 31.21 & 16.1387 & 5.85993 \\
Valid N (listwise) & 45 & & & & \\
\hline
\end{tabular}

Sumber: Data Diolah, 2018

Berdasarkan tabel 1 diketahui rata-rata pengalokasian belanja modal oleh pemerintah pada kabupaten/kota di provinsi Bali periode 2012-2016 adalah sebesar 16,14 persen dari belanja daerahnya, terendah sebesar 5,57 persen dimiliki oleh kabupaten Tabanan, dan tertinggi sebesar 31,21 persen dimiliki oleh kabupaten Badung. Rata - rata rasio derajat desentralisasi fiskal pada 
kabupaten/kota di Provinsi Bali periode 2011-2015 adalah sebesar 24,20 persen, terendah 4,23 persen dimiliki oleh kabupaten Bangli, dan tertinggi 80,36 persen dimiliki oleh kabupaten Badung. Jika dilihat dari rata-rata rasio derajat desentralisasi fiskal kabupaten/kota di provinsi Bali berada pada kategori sedang. Rata - rata rasio kemandirian keuangan daerah pada kabupaten/kota di Provinsi Bali periode 2011-2015 adalah sebesar 60,03 persen, terendah 4,41 persen dimiliki oleh kabupaten Bangli, dan tertinggi 409,11 persen dimiliki oleh kabupaten Badung. Jika dilihat dari rata-rata rasio kemandirian keuangan daerah kabupaten/kota di provinsi Bali berada pada kategori sedang.

Rata - rata rasio efektivitas PAD pada kabupaten/kota di Provinsi Bali periode 2011-2015 adalah sebesar 130,87 persen, terendah 91,00 persen dimiliki oleh kabupaten Jembrana, dan tertinggi 236,28 persen dimiliki oleh kabupaten Karangasem. Jika dilihat dari rata-rata rasio efektivitas PAD kabupaten/kota di provinsi Bali juga berada pada kategori sangat baik. Rata - rata rasio efisiensi keuangan daerah pada kabupaten/kota di Provinsi Bali periode 2011-2015 adalah sebesar 95,04 persen, terendah 0,09 persen dimiliki oleh kabupaten Gianyar, dan tertinggi 108,36 persen dimiliki oleh kabupaten Gianyar juga ditahun yang berbeda. Jika dilihat dari rata-rata rasio efisiensi keuangan daerah kabupaten/kota di provinsi Bali juga berada pada kategori kurang efisien.

Rasio tingkat pembiayaan SiLPA untuk alokasi belanja modal di provinsi Bali periode 2012-2016, rata-rata sebesar 12,56 persen dimiliki oleh kabupaten Tabanan, terendah 3,62 persen dan tertinggi 32,64 persen dimiliki oleh kabuapten Badung. Rata - rata rasio derajat kontribusi BUMD pada kabupaten/kota di 
Ni Made Deni Indiyanti, Pengaruh Kinerja Keuangan Daerah...

Provinsi Bali periode 2011-2015 adalah sebesar 5,39 persen, terendah 1,65 persen dimiliki oleh kabupaten Gianyar dan tertinggi 12,75 persen dimiliki oleh kabupaten Klungkung.

Analisis regresi linear berganda digunakan untuk mengetahui pengaruh kinerja keuangan daerah diukur dengan rasio derajat dentralisasi fiskal, rasio kemadirian keuangan daerah, rasio efektivitas pendapatan asli daerah (PAD), rasio efisiensi keuangan daerah, rasio tingkat pembiayaan SiLPA dan rasio derajat kontribusi BUMD terhadap alokasi belanja modal kabuapten/kota di provinsi Bali.

Tabel 2.

Hasil Analisis Regresi Linear Berganda Coefficients $^{\mathrm{a}}$

\begin{tabular}{|c|c|c|c|c|c|}
\hline \multirow[b]{2}{*}{ Model } & \multicolumn{2}{|c|}{$\begin{array}{c}\text { Unstandardized } \\
\text { Coefficients }\end{array}$} & \multirow{2}{*}{$\begin{array}{c}\begin{array}{c}\text { Standardized } \\
\text { Coefficients }\end{array} \\
\text { Beta }\end{array}$} & \multirow[b]{2}{*}{$\mathrm{T}$} & \multirow[b]{2}{*}{ Sig. } \\
\hline & $\mathrm{B}$ & Std. Error & & & \\
\hline $1 \quad$ (Constant) & 11.730 & 3.577 & & 3.280 & .002 \\
\hline Derajat Desentralisasi Fiskal & .158 & .043 & .547 & 3.655 & .001 \\
\hline Rasio Kemandirian Keuangan Daerah & .027 & .009 & .309 & 3.031 & .004 \\
\hline Rasio Efektivitas PAD & -.034 & .022 & -.091 & -1.559 & .127 \\
\hline Rasio Efisiensi Keuangan Daerah & -.015 & .020 & -.043 & -.722 & .474 \\
\hline Rasio Tingkat Pembiayaan SiLPA & .263 & .119 & .236 & 2.215 & .033 \\
\hline Derajat Kontribusi BUMD & .260 & .122 & .135 & 2.133 & .039 \\
\hline
\end{tabular}

a. Dependent Variable: Alokasi Belanja Modal

Sumber: Data Diolah, 2018

Berdasarkan hasil analisis regresi linear berganda pada tabel 2 maka persamaan regresi yang digunakan dalam penelitian ini yaitu.

$\mathrm{Y}=11,730+0,158 \mathrm{X}_{1}+0,027 \mathrm{X}_{2}-0,034 \mathrm{X}_{3}-0,015 \mathrm{X}_{4}+0,263 \mathrm{X}_{5}+0,260 \mathrm{X}_{6} \varepsilon i$ Keterangan:

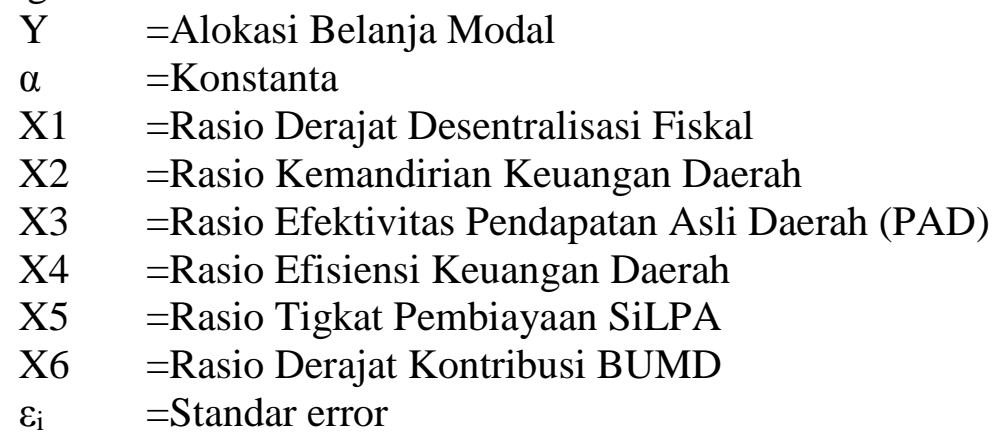


Nilai konstanta sebesar 11,730 menunjukkan bahwa apabila nilai Rasio derajat desentralisasi Fiskal $\left(\mathrm{X}_{1}\right)$, rasio kemandirian keuangan daerah $\left(\mathrm{X}_{2}\right)$, rasio efektivitas $\mathrm{PAD}\left(\mathrm{X}_{3}\right)$, rasio efisiensi keuangan daerah $\left(\mathrm{X}_{4}\right)$, rasio tigkat pembiayaan SiLPA $\left(\mathrm{X}_{5}\right)$, dan rasio derajat kontribusi BUMD $\left(\mathrm{X}_{6}\right)$ sama dengan nol, maka nilai Alokasi Belanja Moda (Y) sama dengan sebesar 11,730 persen.

Variabel rasio derajat desentralisasi fiskal memiliki koefisien regresi sebesar 0,158 dan nilai signifikansi sebesar 0,001 lebih kecil dari 0 , 05, menunjukkan bahwa variabel rasio derajat desentralisasi fiskal berpengarush signifikan terhadap alokasi belanja modal. Koefisien regresi yang bernilai positif menunjukkan pengaruh positif rasio derajat desentralisasi fiskal terhadap alokasi belanja modal, sehingga membuktikan $\mathrm{H}_{1}$ diterima dan $\mathrm{H}_{0}$ ditolak. Kenaikan setiap 1 persen dari rasio desentralisasi fiskal tahun lalu berpengaruh terhadap peningkatan alokasi belanja modal tahun berikutnya sebesar 0,158 persen.

Koefisien regresi variabel rasio kemandirian keuangan daerah sebesar 0,027 dan nilai signifikansinya sebesar 0,004 lebih kecil dari 0, 05. Hal ini berarti bahwa variabel rasio kemandirian keuangan daerah berpengaruh signifikan terhadap alokasi belanja modal. Koefisien regresi yang bernilai positif menunjukkan pengaruh positif rasio kemandirian keuangan daerah terhadap alokasi belanja modal, sehingga menunjukkan bahwa $\mathrm{H}_{2}$ diterima dan $\mathrm{H}_{0}$ ditolak. Kenaikan setiap 1 persen dari rasio kemandirian keuangan daerah tahun lalu berdampak pada peningkatan alokasi belanja modal tahun berikutnya sebesar 0,027 persen.

Koefisien regresi variabel rasio efektivitas pendapatan asli daerah sebesar $-0,034$ dan nilai signifikansinya sebesar 0,127 lebih besar dari 0,05 . Hal ini 
Ni Made Deni Indiyanti, Pengaruh Kinerja Keuangan Daerah...

menunjukkan bahwa variabel rasio efektivitas PAD berpengaruh tidak signifikan terhadap alokasi belanja modal. Koefisien regresi yang bernilai negatif menunjukkan pengaruh negatif rasio efektivitas PAD terhadap alokasi belanja modal, sehingga hal tersebut membuktikan bahwa $\mathrm{H}_{3}$ ditolak. Kenaikan setiap 1 persen dari rasio efektivitas PAD tahun lalu berdampak pada penurunan alokasi belanja modal tahun berikutnya sebesar 0,034 persen.

Variabel rasio efisiensi keuangan daerah memilki koefisien regresi sebesar $-0,015$ dan nilai signifikansinya sebesar 0,474 lebih besar dari 0,05 . Hal ini berarti bahwa variabel efisiensi keuangan daerah berpengaruh tidak signifikan terhadap alokasi belanja modal. Koefisien regresi yang bernilai negatif menunjukkan arah negatif pengaruh rasio efisiensi keuangan daerah terhadap alokasi belanja modal, sehingga membuktikan bahwa $\mathrm{H}_{4}$ ditolak. Kenaikan setiap 1 persen dari rasio efisiensi keuangan daerah tahun lalu berpengaruh terhadap penurunan alokasi belanja modal tahun berikutnya sebesar 0,015 persen.

Koefisien regresi variabel rasio tingkat pembiayaan SiLPA sebesar 0,263 dengan nilai signifikansinya sebesar 0,033 lebih kecil dari 0 , 05. Hal ini membuktikan bahwa rasio tingkat pembiayaan SiLPA berpengaruh signifikan pada aloaksi belanja modal. Koefisien regresi yang bernilai positif menunjukkan pengaruh positif rasio tingkat pembiayaan SiLPA teradap alokasi belanja modal, sehingga $\mathrm{H}_{5}$ diterima dan $\mathrm{H}_{0}$ ditolak. Kenaikan setiap 1 persen dari rasio tingkat pembiayaan SiLPA akan berdampak pada peningkatan alokasi belanja modal tahun berikutnya sebesar 0,263 persen. 
Koefisien regresi variabel rasio derajat kontribusi BUMD pada tabel 2, sebesar 0, 260 dengan nilai signifikansinya sebesar 0, 39 lebih kecil dari 0, 05 . Menunjukkan bahwa variabel rasio derajat kontribusi BUMD berpengaruh signifikan terhadap alokasi belanja modal. Koefisien regresi yang bernilai positif menunjukkan pengaruh positif rasio derajat kontribusi BUMD terhadap aloaksi belanja modal, sehingga membuktikan bahwa $\mathrm{H}_{6}$ diterima. Kenaikan setiap 1 persen dari rasio derajat kontribusi BUMD tahun lalu akan berpengaruh terhadap kenaikan belanja modal tahun berikutnya sebesar 0,260 persen.

Tabel 3.

Hasil Uji Normalitas

One-Sample Kolmogorov-Smirnov Test

\begin{tabular}{llr}
\hline & & $\begin{array}{c}\text { Unstandardized } \\
\text { Residual }\end{array}$ \\
\hline $\mathrm{N}$ & Mean & 45 \\
Normal Parameters & .0000000 \\
& Std. Deviation & 1.79745992 \\
Most Extreme Differences & Absolute & .169 \\
& Positive & .169 \\
& Negative & -.143 \\
Test Statistic & 1.135 \\
Asymp. Sig. (2-tailed) & $.152^{c}$ \\
\hline a. Test distribution is Normal. & \\
b. Calculated from data. & \\
c. Lilliefors Significance Correction. \\
\multicolumn{2}{l}{ Sumber: Data Diolah, 2018 }
\end{tabular}

Tabel 3 menunjukkan niali Asymp. Sig (2-tailed) yang diperoleh sebesar 0,152, nilai tersebut lebih besar dari tingkat $\alpha$ sebesar 0,05 . Hal ini menunjukkan data dari model regresi dalam penelitian ini telah berdistribusi normal. 


\section{Tabel 4}

\section{Hasil Uji Autokorelasi}

Model Summary ${ }^{\mathrm{b}}$

\begin{tabular}{|c|c|c|c|c|c|}
\hline Model & $\mathrm{R}$ & R Square & $\begin{array}{l}\text { Adjusted R } \\
\text { Square }\end{array}$ & $\begin{array}{l}\text { Std. Error of the } \\
\text { Estimate }\end{array}$ & Durbin-Watson \\
\hline 1 & $.935^{\mathrm{a}}$ & .874 & .854 & 1.934166 & 2.003 \\
\hline \multicolumn{6}{|c|}{$\begin{array}{l}\text { a. Predictors: (Constant), Derajat Kontribusi BUMD, Rasio Efektivitas PAD, Rasio } \\
\text { Tingkat Pembiayaan SiLPA, Rasio Efisiensi Keuangan Daerah, Rasio Kemandirian } \\
\text { Keuangan Derah, Derajat Desentralisasi Fiskal }\end{array}$} \\
\hline \multicolumn{6}{|c|}{ b. Dependent Variable: Alokasi Belanja Modal } \\
\hline
\end{tabular}

Tabel 4 menunjukkan nilai Durbin-Waston sebesar 2,003, pada tabel Durbin Waston dengan $\mathrm{n}=45, \mathrm{k}=7$, dan tingkat signifikan $5 \%$ menunjukkan nilai $\mathrm{d}_{\mathrm{L}}=$ 1,189 dan $\mathrm{d}_{\mathrm{u}}=1,895$. Nilai Durbin Waston 2, 003 lebih besar dari batas atas $\mathrm{d}_{\mathrm{u}}$ yakni 1, 895 dan kurang dari $\left(4-d_{u}\right) 4-1,895=2,105$, maka pengujian dengan Durbin Waston berada pada daerah tidak terdapat autokorelasi sehingga model regresi yang digunakan tidak terdapat gejala autokorelasi.

Tabel 5.

Hasil Uji Heteroskedastisitas Coefficients $^{\mathrm{a}}$

\begin{tabular}{|c|c|c|c|c|c|}
\hline & \multirow{2}{*}{\multicolumn{2}{|c|}{$\begin{array}{l}\text { Unstandardized } \\
\text { Coefficients }\end{array}$}} & & & \\
\hline \multirow[b]{2}{*}{ Model } & & & \multirow{2}{*}{$\begin{array}{c}\text { Standardized } \\
\text { Coefficients } \\
\text { Beta }\end{array}$} & \multirow[b]{2}{*}{$\mathrm{T}$} & \multirow[b]{2}{*}{ Sig. } \\
\hline & B & $\begin{array}{l}\text { Std. } \\
\text { Error }\end{array}$ & & & \\
\hline 1 (Constant) & .716 & 2.659 & & .269 & .789 \\
\hline Derajat Desentralisasi Fiskal & .013 & .032 & .167 & .399 & .692 \\
\hline Rasio Kemandirian Keuangan Daerah & -.003 & .007 & -.127 & -.448 & .657 \\
\hline Rasio Efektivitas PAD & .000 & .016 & .000 & .001 & .999 \\
\hline Rasio Efisiensi Keuangan Daerah & .009 & .015 & .096 & .583 & .563 \\
\hline Rasio Tingkat Pembiayaan SiLPA & -.023 & .088 & -.079 & -.266 & .792 \\
\hline Derajat Kontribusi BUMD & -.053 & .091 & -.103 & -.582 & .564 \\
\hline
\end{tabular}

a. Dependent Variable: ABS_RES

Sumber: Data Diolah, 2018

Tabel 5 menunjukkan nilai signifikansi masing-masing variabel independen terhadap nilai absolute residual yang lebih besar dari 0, 05 sehingga dapat disimpulkan bahwa tidak terdapat masalah heteroskedastisitas pada penelitian ini. 
Tabel 6.

Hasil Uji Multikolinearitas

Coefficients $^{\mathrm{a}}$

\begin{tabular}{llll}
\hline & & \multicolumn{2}{c}{ Collinearity Statistics } \\
\cline { 2 - 3 } Model & \multicolumn{2}{c}{ Tolerance } & VIF \\
\hline $1 \quad$ (Constant) & .148 & 6.759 \\
$\quad$ Derajat Desentralisasi Fiskal & .318 & 3.141 \\
$\quad$ Rasio Kemandirian Keuangan Daerah & .980 & 1.021 \\
Rasio Efektivitas PAD & .945 & 1.058 \\
Rasio Efisiensi Keuangan Daerah & .292 & 3.421 \\
$\quad$ Rasio Tingkat Pembiayaan SiLPA & .830 & 1.206 \\
$\quad$ Derajat Kontribusi BUMD & & \\
\hline a. Dependent Variable: Alokasi Belanja Modal & & \\
Sumber: Data Diolah, 2018 & &
\end{tabular}

Tabel 6 menunjukkan masing-masing variabel independen memiliki nilai tolerance lebih besar dari 0,1 dan nilai VIF lebih kecil dari 10, maka dapat disimpulkan bahwa data pada penelitian ini tidak mengandung multikolinearitas.

Tabel 7.

Koefisien Determinasi Model Summary

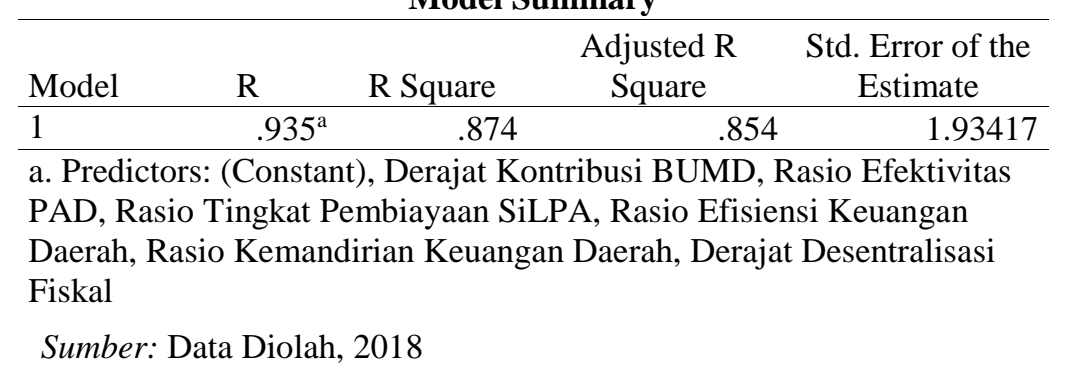

Tabel 7 dibawah ini, menunjukkan koefisien determinasi dengan paramenter $\mathrm{R}^{2}$ sebesar 0,874 . Hal ini berarti bahwa variabel bebas rasio derajat desentralisasi fiskal, rasio kemandirian keuangan daerah, rasio efektivitas PAD, rasio efisiensi keuangan daerah, rasio tingkat pembiayaan SiLPA, rasio derajat kontribusi BUMD berpengaruh pada alokasi belanja modal sebesar 87,4 persen sisanya sebesar 12,6 peresen dipengaruhi oleh variabel lain diluar model. 
Tabel 8.

Hasil Uji Kelayakan Model

\begin{tabular}{llrrrrr}
\multicolumn{7}{c}{ ANOVA $^{\mathbf{a}}$} \\
\hline Model & & Sum of Squares & Df & Mean Square & F & Sig. \\
\hline 1 & Regression & 984.800 & 6 & 164.133 & 43.874 & $.000^{\mathrm{b}}$ \\
& Residual & 142.158 & 38 & 3.741 & & \\
& Total & 1126.958 & 44 & & & \\
\hline
\end{tabular}

a. Dependent Variable: Alokasi Belanja Modal

b. Predictors: (Constant), Derajat Kontribusi BUMD, Rasio Efektivitas PAD, Rasio Tingkat Pembiayaan SiLPA, Rasio Efisiensi Keuangan Daerah, Rasio Kemandirian Keuangan Daerah, Derajat Desentralisasi Fiskal

Sumber: Data Diolah, 2018

Tabel 8 menunjukkan nilai $P$-value pada sebesar 0,000 signifikansi pada $\alpha=$ 5\%, maka dapat diakatakan model regresi linier berganda penelitian ini telah memenuhi uji kelayakan model.

\section{Pengaruh Rasio Derajat Desentralisasi Fiskal Terhadap Alokasi Belanja Modal}

Penelitian ini menunjukan bahwa rasio derajat desentralisasi fiskal memiliki pengaruh positif signifikan terhadap besar kecilnya pengalokasian belanja modal. Apabila rasio desentralisasi fiskal mengalami peningkatan berarti kinerja keuangan daerah semakin baik, sehingga pengalokasian terhadap belanja modal daerah mengalami peningkatan. Meningkatnya pendapatan asli daerah yang diterima, didukung dengan adanya kebijakan desentralisasi fiskal. Pemerintah daerah mengupayakan peningkatana aloaksi belanja modal untuk penyediaan sarana dan prasaran untuk kebutuhan masyarakt. Peningkatan alokasi belanja modal tersebut dapat meningkatkan kesejahteraan masyarakat dan juga pertumbuhan ekonomi di daerah tersebut. Hasil penelitian ini mendukung hasil penelitian dari Arsa dan Setiawian (2015), Huda (2015) dan Praza (2016). 


\section{Pengaruh Rasio Kemandirian Keuangan Daerah Terhadap Alokasi Belanja} Modal

Hasil penelitian ini menunjukkan rasio kemandirian keuangan daerah berpengaruh positif signifikan terhadap alokasi belanja modal. Rasio kemandirian daerah yang semakin tinggi berarti bahwa tingkat ketergantungan daerah terhadap bantuan pihak eksternal terutama pemerintah pusat dan provinsi semakin rendah. Hal ini juga mengartikan bahwa kemampuan daerah dalam membiayai sendiri kegiatan pemerintahan, pembangunan, dan pelayanan publik kepada masyarakat mengalami peningkatan sehingga pengalokasian terhadap belanja modal juga mengalami peningkatan. Sebaliknya jika rasio kemandirian daerah rendah maka alokasi terhadap belanja modal juga mengalami penurunan. Hasil penelitian ini mendukung penelitian dari Sularso dan Restianto (2011) dan Jatitmas (2015)

\section{Pengaruh Rasio Efektivitas Pendapatan Asli Daerah Terhadap Alokasi Belanja Modal}

Penelitian ini menunjukkan rasio efektivitas PAD berpengaruh negatif namun tidak signifikan terhadap besar kecilnya alokasi belanja modal. Tinggi rendahnya rasio efektivitas PAD tidak berpengaruh signifikan terhadap alokasi belanja modal. Kondisi ini disebabkan oleh kecenderungan diabaikannya pemenuhan kebutuhan masyarakat, sehingga pengalokasian belanja modal tidak terealisasikan secara maksimal. Pencapaian PAD yang lebih besar dari targetnya, seharusnya dapat meningkatkan pengalokasikan pada belanja modal, namun pemerintah kabupaten/kota di Provinsi Bali lebih banyak menggunakan pendapatan asli daerah tersebut untuk memenuhi belanja pegawai. Hasil penelitian 
Ni Made Deni Indiyanti, Pengaruh Kinerja Keuangan Daerah...

ini mendukung penelitian dari Tamawiwy dkk. (2015), Martini dan Dwirandra (2015) dan Praza (2016)

\section{Pengaruh Rasio Efisiensi Keuangan Daerah Terhadap Alokasi Belanja Modal}

Penelitian ini menunjukkan hasil bahwa rasio efisensi keuangan daerah berepngaruh negatif namun tidak signifikan terhadap besar kecilnya alokasi belanja modal. Semakin tinggi rasio efisiensi keuangan daerah berarti daerah tersebut semakin tidak efisien. Tinggi rendahnya rasio efisiensi keuangan daerah tidak signifikan mempengaruhi alokasi belanja modal. Hal tersebut disebabkan oleh realisasi pengeluaran daerah lebih besar dari pendapatan yang diterima sehingga terjadi pemborosan, tetapi kurang dimaksimalkan untuk belanja modal. Pengeluaran yang seharusnya diprioritaskan untuk pelayanan publik yang dalam hal ini untuk pemenuhan aset tetap daerah berupa belanja modal, tidak terealisasikan dengan baik. Hasil penelitian ini sejalan dengan penelitian Tamawiwy dkk. (2015).

\section{Pengaruh Rasio Tingkat Pembiayaan SiLPA Terhadap Alokasi Belanja Modal}

Penelitian ini menunjukkanrasio tingkat pembiayaan SiLPA berpengaruh positif signifikan terhadap alokasi belanja modal. Besar kecilnya alokasi belanja modal tahun berikutnya yang dilakukan oleh pemerintah kabupaten/kota di provinsi Bali dipengaruhi oleh rasio tingkat pembiayaan SiLPA tahun lalu. SiLPA yang besar dikabupaten/kota di Provinsi Bali harus diminimalkan, salah satunya dengan pengoptimalan penggunaan SiLPA tahun sebelumnya untuk meningkatkan penyerapan belanja modal diharapkan akan memberikan stimulus 
bagi peningkatan pelayanan publik serta pertumbuhan dan produtivitas perekonomian kabupaten/kota di provinsi Bali. SiLPA yang dimiliki kabuapaten/kota di provinsi Bali tidak selamnya berarti buruk, namun tergantung oleh faktor yang menyebabkan SiLPA itu ada. Hasil penelitian ini sejalan dengan penelitian Hidayat (2013).

\section{Pengaruh Rasio Derajat Kontribusi BUMD Terhadap Alokasi Belanja Modal}

Hasil penelitian ini menunjukkan bahwa rasio derajat kontribusi BUMD memiliki pengaruh positif signifikan terhadap besar kecilnya alokasi belanja modal. Kontribusi BUMD menjadi suatu sumber dari pendapatan asli daerah, sehingga tingginya derajat kontribusi BUMD diharapkan mampu meningkatkan pendapatan daerahnya. Pendapatan daerah yang tinggi diharapakan mampu digunakan untuk memenuhi kebutuhan untuk kesejahteraan masyarakat khusunya untuk belanja modal. Kontribusi laba BUMD yang diterima oleh pemerintah daerah di provinsi Bali lebih banyak di peruntukan untuk belanja modal dibandingkan dengan belanja lainnya. Penelitian ini sejalan dengan penelitian Sularso dan Restianto (2011).

\section{IMPLIKASI HASIL PENELITIAN}

Rasio derajat desentralisasi fiskal berpengaruh positif signifikan terhadap alokasi belanja modal kabupaten/kota di provinsi Bali. Tingginya pendapatan asli daerah yang diterima oleh pemerintah daerah, maka semakin tinggi juga belanja modal yang dapat dialokasikan. Pemerintah kabupaten/kota di Provinsi Bali harus selalu memperhatikan dan tidak mengabaikan kebutuhan masyarakatnya. 
Ni Made Deni Indiyanti, Pengaruh Kinerja Keuangan Daerah...

Rasio kemandirian keuangan daerah berpengaruh positif signifikan terhadap alokasi belanja modal kabupaten/kota di provinsi Bali. Meningkatnya pendapatan asli daerah akan mengurangi ketergantungan daerah terhadap pemerintah pusat dan/atau provinsi, sehingga dengan hal tersebut daerah dapat mencukupi belanja modal daerahnya.

Rasio efektivitas pendapatan asli daerah berpengaruh negatif tidak signifikan terhadap alokasi belanja modal kabupaten/kota di provinsi Bali. Kabuputen/kota di provinsi Bali rata-rata memiliki rasio efektivitas pendapatan asli daerah yang berada pada kategori sangat efektif berarti kinerja keuangan daerahnya sangat baik namun, pendapatan asli daerah yang diterima oleh pemerintah daerah tersebut lebih banyak dialokasikan ke belanja pegawai dibandingkan ke belanja modal. Hal tersebut berarti bahwa pemerintah daerah setempat cenderung mengabaikan tuntutan kebutuhan masyarakatnya.

Rasio efisiensi keuangan daerah berpengaruh negatif tidak signifikan signifikan terhadap alokasi belanja modal kabupaten/kota diprovinsi Bali. Ratarata rasio efisiensi keuangan daerah kabupaten/kota di provinsi Bali berada pada kategori tidak efisien berarti bahwa tingkat pengeluaran lebih banyak dibandingkan pendapatan yang diterima, sehingga terjadi pemborosan namun dalam hal ini tidak dimaksimalkan untuk belanja modal.

Rasio tingkat pembiayaan SiLPA berpengaruh positif signifikan terhadap alokasi belanja modal kabupaten/kota di provinsi Bali. Tingkat Pembiayaan SiLPA tersebut akan membantu pemerintah daerah untuk memenuhi belanja pemerintah yang terkadang melebihi dari pendapatan daerah, termasuk belanja 
modal. SiLPA yang terbentuk sebaiknya dimanfaatkan untuk penyerapan pada belanja modal.

Rasio derajat kontribusi BUMD berpengaruh positif signifikan terhadap aloaksi belanja modal kabupaten/kota di provinsi Bali. Kontribusi laba yang diteriam pemerintah kabupaten/kota di provinsi Bali dari badan usaha milik daerah (BUMD) memiliki rata-rata yang cukup kecil, namun kontribusi laba tersebut dapat membantu pemerintah daerah untuk pemenuhan belanja daerahnya.

\section{SIMPULAN DAN SARAN}

Berdasarkan hasil penelitian serta pembahasan, maka dapat diambil simpulan sebagai berikut: 1) Rasio derajat desentralisasi fiskal tahun lalu berpengaruh positif signifikan terhadap alokasi belanja modal tahun berikutnya pada kabupaten/kota di Provinsi Bali. 2) Rasio kemandirian keuangan daerah tahun lalu berpengaruh positif signifikan terhadap alokasi belanja modal tahun berikutnya pada kabupaten/kota di provinsi Bali. 3) Rasio efektivitas PAD tahun lalu berpengaruh negatif namun tidak signifikan terhadap alokasi belanja modal tahun berikutnya pada kabupaten/kota di Provinsi Bali. 4) Rasio efisiensi keuangan daerah tahun lalu berpengaruh negatif namun tidak signifikan terhadap aloaksi belanja modal tahun berikutnya pada kabupaten/kota di provinsi Bali. 5) Rasio tingkat pembiayaan SiLPA tahun lalu berpengaruh positif terhadap alokasi belanja modal tahun berikutnya pada kabupaten/kota di provinsi Bali. 6) Rasio derajat kontribusi BUMD tahun lalu berpengaruh positif signifikan terhadap alokasi belanja modal tahun berikutnya pada kabupaten/kota di provinsi Bali. 
Ni Made Deni Indiyanti, Pengaruh Kinerja Keuangan Daerah...

Berdasarkan simpulan yang telah dikemukakan maka dapat disarankan beberapa hal sebagai berikut: 1) Pemerintah daerah juga sebaiknya lebih cermat dalam menggali potensi-potensi daerah, yang dapat meningkatkan pendapatan asli daerah, sehingga dapat tercipta keuangan daerah yang mandiri sesuai dengan tujuan otonomi daerah. 2) Pendapatan asli daerah yang diterima oleh pemerintah kabupaten/kota di provinsi Bali, dimanfaatkan sebaik-baiknya untuk kepentingan masyarakat seperti pengalokasian kepada belanja modal untuk penyediaan sarana dan prasaran yang dapat meningkatkan pertumbuhan ekonomi dan kesejahteraan masyarakat di daerah tersebut. 3) Pemerintah kabupaten/kota di Provinsi Bali perlu menghitung dengan cermat besarnya pengeluaran untuk merealisasikan seluruh pendapatan yang diterima tersebut. 4) Peneliti selanjutnya diharapkan dapat menggunakan rasio-rasio lainnya yang tidak digunakan dalam penelitian ini untuk lebih memaksimalkan analisis kinerja keuangan daerah, seperti rasio keserasian belanja, rasio pertumbuhan PAD, rasio efisiensi belanja, dll. Penelitian ini, juga diharapkan dikembangkan dengan pengamatan secara langsung pada pemerintah daerah dan wawancara pada pihak terkait.

\section{REFERENSI}

Abu, Nurudeen. and Abdullahi, Usman. 2010. Government Expenditure and Economic Growth in Nigeria, 1970-2008: A Disaggregated Analysis. Business and Economic Journal, 4(3): 237-330.

Amuka, Joseph I., Miracle O. Ezeoke., and Fredrick O. Asogwa. 2016. Government Spending Pattern and Macroeconomic Stability: A Vector Autoregressive Model. International Journal of Economics and Financial Issue, 6(4): 1930-1936.

Ardhini dan Sri Handayani. 2011. Pengaruh Rasio Keuangan Daerah Terhadap Belanja Modal untuk Pelayanan Publik dalam Perspektif Teori Keagenan 
(Studi pada Kabupaten dan Kota di Jawa Tengah). Undergraduate Thesis. Universitas Diponegoro.

Arsa, I Ketut, dan Nyoman Djinar Setiawina. 2015. Pengaruh Kinerja Keuangan Terhadap Alokasi Belanja Modal dan Pertumbuhan Ekonomi Pemerintah Kabupaten/Kota Se-Provinsi Bali Tahun 2006 S.D. 2013. Jurnal Buletin Studi Ekonomi, 20 (2):104-111

Badan Pusat Statistik.2014. Statistik Keuangan Pemerintah Kabupaten/Kota SeProvinsi Bali Tahun 2010-2014. http://www.bali.bps.co.id. (Diunduh tanggal 7 Juli 2017).

Badan Pusat Statistik.2015.Statistik Keuangan Pemerintah Kabupaten/Kota SeProvinsi Bali Tahun 2011-2015. http://www.bali.bps.co.id. (Diunduh tanggal 7 Juli 2017).

Badan Pusat Statistik. 2016. Statistik Keuangan Pemerintah Kabupaten/Kota SeProvinsi Bali Tahun 2012-2016. http://www.bali.bps.co.id. (Diunduh tanggal 7 September 2017).

Badrudin, Rudy. 2011. Effect of Fiscal Decentralization on Capital Expenditure, Growth, and Welfare. Economic Journal of Emerging Markets, 3 (3):211223.

Bastian, Indra.2001. Akuntansi Sektor Publik di Indonesia. Yogyakarta: BPFEYogyakarta.

Bojanic, Antonio N. 2013. The Composition of Government Expenditure and Economic Growt In Bolivia. Latin American Journal of Economic, 50(1): 83-105.

Coestzee, C.E. and Kleynhans, E.P.J. 2017. The Contribution of Public Capital Towards Economic Growth: A Kwazulu-Natal Case Study. South African Journal of Economic and Financial Review, 20(1): 1-10.

Doh-Nani, Richard and Dadson Awunyo-Vitor. 2012. The Causal Link Between Government Expenditure and Government Revenue in Ghana. Asian Economic and Financial Review, 2(2): 382-388.

Egbetunde, Tajudeen and Ismail O. Fasanya. 2014. Public Expendenture and Economic Growth in Nigeria: Evidence From Auto-Regressive Distributed Lag Specification. Zegreb International Review of Economics \& Business, 17(2): 45-58.

Fasoranti, Mary Madupe. 2012. The Effect of Government Expenditure on Infrastructure on the Growth of the Nigerian Economy, 1977-2009. International Journal of Economics and Financial Issue, 2(4): 513-518. 
Gerungan, Sylvia Febriany., David. P.E. Saerang., dan Winston Pontoh. 2015. Pengaruh Kinerja Keuangan Kabupaten/Kota Terhadap Alokasi Belanja Modal di Provinsi Sulawesi Utara. Jurnal Riset Akuntansi dan Auditing "Goodwill”, 6 (1):12-29.

Hafidh, Aula Ahmad. 2013. Analisis Rasio Keuangan Daerah dalam Mempengaruhi Belanja Modal Publik Bagi Pertumbuhan Ekonomi. Jurnal Penelitian Humaniora, 8 (2):109-120

Halim, Abdul dan Theresia Damayanti. 2007. Pengelolaan Keuangan Daerah edisi 2. Yogyakarta: Sekolah Tinggi Ilmu Manajemen YKPN.

Halim, Abdul. 2008. Akuntansi Keuangan Daerah edisi 3. Jakarta: Salemba Empat.

Halim, Abdul. 2014. Manajemen Keuangan Sektor Publik. Jakarta: Salemba Empat.

Hidayat, Mochamad Fajar. 2013. Analisis Pengaruh Kinerja Keuangan Daerah terhadap Alokasi Belanja Modal. Jurnal Ilmiah Mahasiswa Fakultas Ekonomi dan Bisnis (JIMFEB), 1 (2):1-21.

Huda, Ahmad Syahral. 2015. Pengaruh Kinerja Keuangan, Fiscal Stress, dan Kepadatan Penduduk Terhadap Alokasi Belanja Modal di Nusa Tenggara Barat. ASSETS, 5 (2):1-12.

Jatitmas, Rilo. 2015. Pengaruh Rasio Keuangan Terhadap Alokasi Belanja Modal pada Kabupaten/Kota di Provinsi Jawa Tengah. Jurnal Akuntansi dan Sistem Teknologi Informasi, 11 (1):50-57.

Jin, Tao and Jianhui Zhang.2011. Effect of Local Government Expenditure on The Ratio of Output to Capital: Evidence From Panel Data at China's Provincial Level. Frot. Econ. China, 6(2): 249-270.

Kayode, Ayinde, John Kuranga, and Adewale F. Lukman. 2015. Modeling Nigerian Government Expenditure, Revenue And Economic Growth: CoIntegration, Error Correction Mechanism And Combined Estimators Analysis Approach. Asian Economic and Financial Review, 5(6): 858-867.

Mahmudi.2010. Manajemen Keuangan Daerah. Jakarta: Penerbit Erlangga.

Mahsun, Mohamad, Firman Sulistyowati, dan Heribertus Andre Purwanugraha. 2007. Akuntansi Sektor Publik. Yogyakarta: BPFE

Martini, Kadek, A.A.N.B. Dwirandra. 2015. Pengaruh Kinerja Keuangan Daerah pada Alokasi Belanja Modal di Provinsi Bali. E-Jurnal Akuntansi Universitas Udayana, 10 (2):426-443. 
Nugroho, Fajar dan Abdul Rohman. 2012. Pengaruh Belanja Modal Terhadap Pertumbuhan Kinerja Keuangan Daerah dengan Pendapatan Asli Daerah sebagai Variabel Intervening (Studi Kasus di Provinsi Jawa Tengah. Undergraduate Thesis. Universitas Diponegoro.

Nwosu, Damian C., and Harrison O. Okafor. 2014. Government Revenue and Expenditure in Nigeria: A Disaggregated Analysis. Asian Economic and Financial Review, 4(7): 877-892.

Patricia, Chude Nkiru, and Chude Daniel Izuchukwu. 2013. Impact of Government Expenditure in Nigeria: ADisaggregated Analysis. Asian Economic and Financial Review, 1(2): 64-71.

Praza, Eko Indra. 2016. Analisis Pengaruh Kinerja Keuangan Terhadap Alokasi Belanja Modal di Provinsi Jambi. Jurnal Perspektif dan Pembangunan Daerah, 4 (1):25-35.

Prihastuti, Asepma Hygi, Taufeni Taufik, dan Restu Agusti.2015. Pengaruh Kinerja Keuangan Terhadap Alokasi Belanja Modal dan Pertumbuhan Ekonomi di Kabupaten/Kota Riau. Jurnal SOROT, 10 (2):143-154

Puspaningsih, Desak Putu Dwi dan Ni Ketut Lely Aryani M.2016.Kinerja Keuangan Daerah Sebagai Pemoderasi Pengaruh Dana Bagi Hasil dan Belanja Langsung Terhadap Pertumbuhan Ekonomi.E-Jurnal Akuntansi Universitas Udayana, 15 (3):2213-2239.

Republik Indonesia. 2004. Undang-Undang Republik Indonesia Nomor 33 Tahun 2004 Tentang Perimbangan Keuangan Antara Pemerintah Pusat dan Pemerintah Daerah.

Republik Indonesia. 2006. Peraturan Menteri Dalam Negeri No. 13 Tahun 2006 Tetang Pedoman Pengelolaan Keuangan Daerah.

Rinaldi, Udin. 2012. Kemandirian Keuangan Dalam Pelaksanaan Otonomi Daerah. Jurnal EKSOS, 8 (2):105-113.

Riswan dan Anthony Affandi. 2014. pengaruh Kinerja Keuangan Daerah Terhadap Belanja Modal Untuk Pelayanan Publik Dalam Perspektif Teori Keagenan. Jurnal Akuntansi dan Keuangan, 5 (2):71-90.

Rosemary O Ananazodo, Igbokwe-Ibeto, Chinyeaka Justine, and NKOMAH, Barisua Barry. 2016. Local Government Financial Autonomy: A Comparative Analysis of Nigeria and Brazil. Arabian Journal of Business and Management Review, 5(10): 38-54.

Saruc, NaciTolga and Isa Sagbas. 2008. The Surge Impact of the Flypaper, Sustitution and Stimulation Effect on Local Tax Effort in Turkey. 
International Research Journal Finance and Economics. EuroJournals Publishing, Inc., 13: 42-49.

Sularso, Havid, Y.E. Restianto. 2011. Pengaruh Kinerja Keuangan Terhadap Alokasi Belanja Modal dan Pertumbuhan Ekonomi Kabupaten/Kota do Jawa Tengah. Media Riset Akuntansi, 1 (2):109-124

Suwandi, Kurnia., Afrizal Tahar. 2015. Pengaruh Kinerja Keuangan Terhadap Pertumbuhan Ekonomi Daerah dengan Alokasi Belanja Modal sebagai Variabel Intervening (Studi pada Pemerintahan Kabupaten/Kota D.I. Yoyakarta. Jurnal Infestasi, 11 (2):118-136.

Tamawiwy, Julius., Jullie J. Sondakh, dan Jessy D.L. Waronga. 2016. Pengaruh Kinerja Keuangan Pemerintah Daerah Terhadap Belanja Modal untuk Pelayanan Publik (Studi pada Kabupaten dan Kota di Provinsi Sulawesi Utara). Jurnal Riset Akuntansi dan Auditing “Goodwill”, 7 (2):103-124.

Udoka, Chris O. and Roland A Anyingang. 2015. The Effect Of Public Expenditure On The Growth And Development Of Nigerian Economy (1980-2012). International Review of Management and Business Research, 4(3): 823-834.

Usman, A.,H.I. Mobolaji, M.A. Yaru, and T.A. Yakubu. 2011. Public Expenditure And Economic Growth In Nigeria. Asian Economic and Financial Review, 1(3): 104-113.

Utama, Made Suyana. 2014. Buku Ajar Aplikasi Analisis Kuantitatif. Edisi 8. Fakultas Ekonomi dan Bisnis Universitas Udayana.

Venkataraman, Subramanya and Arabi Urmi.2017. Development Expenditure, Fiscal Consolidation and Public Revenue in India. International Journal of Accounting and Economics Studies, 5(1): 16-18. 